\title{
Establishing Precedents: Women's Student Activism and Social Change in the (Canadian) National Union of Students,1972-1979
}

\author{
Nigel Roy Moses \\ Lakehead University Orillia Campus
}

\section{ABSTRACT}

This article examines young women's activism in the (Canadian) National Union of Students (NUS) from the time that the national student organization regrouped in 1972 to the endorsement of the NUS Declaration of the Rights of the Woman Student in 1979. The focus is on the problems NUS women faced, the solutions and organizational structures they devised, and how they helped transform the social organization of NUS to better represent their interests. This work makes an important contribution to our knowledge of Canadian student organizing and the women's movement. Youth activists guided by a particular set of anti-patriarchal cultural orientations and values not only had a profoundly transformative effect on student organization, but were among the social agents producing a much broader social transformation. In this regard, women student activists throughout the 1970s, among other activists in many other locations, were the women's movement.

\section{RÉSUMÉ}

Cet article examine l'activisme de jeunes femmes dans l'Union nationale (canadienne) des étudiants (UNÉ) au moment du regroupement de l'Union en 1972 jusqu'à l'adhésion à la Déclaration des droits de l'étudiante de l'UNÉ en 1979. L'auteur met l'accent sur les problèmes auxquels sont confrontés les femmes de l'UNÉ, les solutions et les structures qu'elles ont conçues et comment elles ont contribué à transformer l'organisation sociale de l'UNÉ afin que leurs intérêts soient mieux représentés. L'article apporte une contribution importante à notre connaissance de l'organisation des étudiants et du mouvement des femmes au Canada. De jeunes activistes guidées par des orientations culturelles antipatriarcales n'ont pas seulement eu un effet transformateur sur le mouvement étudiant, mais elles ont contribué à l'évolution de l'ensemble des transformations sociales de cette époque. Ainsi, pendant les années 70, les étudiantes activistes ont constitué une composante essentielle du mouvement des femmes.

\section{Introduction}

The National Union of Students (NUS) was a federation of mainly English-speaking Canadian university and college student councils and was part of a long tradition of 
national student organizing that began in 1926. The purpose of NUS was to represent "student interests" mainly to government, university administrators and the public. I explore the problems that NUS women students faced, the issues they addressed. and the solutions and political positions they devised. I describe how women students helped shape and transform the social organization of NUS by challenging and responding to patriarchal belief systems and male-dominated organization and decision-making practices.

I begin by outlining a small, yet revealing, Canadian literature on women's student activism before NUS's formation. These discussions help contextualize the main discussion: the influence of women's activism on NUS policies and organizational structures in the 1970s. I highlight several interrelated aspects of NUS women's activism and influence on the NUS organization: (a) their struggle for representation on the NUS executive or Central Committee, (b) their creation and development of the women's caucus, (c) their influence on NUS's organizational development and survival, (d) their success in achieving NUS's official endorsement of a women's right to abortion and finally, (e) their creation of the Declaration of the Rights of the Woman Student.

\section{Literature on Women's Student Activism}

There is no historiography on NUS; nevertheless there is a literature on women students before 1970 that provides some historical context for 1970s women's student activism. At the most general level, what links 1970s women's political engagements to preceding periods was that women students were never passive recipients of patriarchal social relations. Women students of all periods can be interpreted as being culturally productive social agents. The common thread in the small literature on women's student activism is that activism mattered. Certain features of social change in student affairs and in some cases, the very university itself, were directly the outcome of politically mobilized and charged young women. From this perspective, NUS women's student activism of the 1970s should not be viewed as an entirely new phenomenon arising amidst the clamour and legacy of 1960s liberation struggles.

Canadian women's university student activism is the focal subject of a number of historical studies. ${ }^{1}$ Discussions of women's university student activism are also found in the histories of women's participation in Canadian universities. ${ }^{2}$ These works recognize the importance of students in their social analyses of campus life and, taken as a whole, make an important contribution to the history of youth and student culture and activism in Canada before 1950. They enhance our empirical-historical understanding while reinforcing my claim that women students were significant social agents in the transformation of student organizations and the university itself.

In addition to the above cited literature on women and women students in university life, Axelrod and Levi describe student activism in the 1930s and 1940s. While women were not their focus, their studies do provide further context for 1970s women's student activism. Axelrod points out how student councils, the basic units of the National Federation of Canadian University Students (NFCUS) organization, were "virtually always $\mathrm{r}[\mathrm{u}] \mathrm{n}$ " by men. Through a photograph of the 1931 National 
Conference of the Student Christian Movement (SCM) in Muskoka, Axelrod also implies, inadvertently, that this organization was more welcoming to women students than the NFCUS - 80 per cent of the SCM delegates were female. ${ }^{3}$ Levi's focus on local, student council level politics at McGill and Toronto suggests that future study of local conditions in the 1970s (and other periods) would usefully complement this article's national perspective. ${ }^{4}$

Kostash discusses the "rising of the women" in the 1960s and is perhaps the most informative retrospective text we have on women student activism of the 1960s. ${ }^{5}$ Women activists in new left Student Union for Peace Action of the mid-1960s expressed anger towards male counterparts for their sexist behaviours and attitudes, ${ }^{6}$ yet by 1970, key male voices were heard from within the student and youth-based new left calling for "women's liberation." In "Children of Privilege..." Levitt suggests that feminist student activism in the late 1960s was a key factor in the socalled "end" of the new left student and youth based movements. ${ }^{8}$ It is clear from my research and that of others, however, that the new left student politics was not simply undermined by the women's movement, but was a major social agent of its transformation. Owram discusses the women's movement of the 1960s in terms of the demographic, generational and technological factors underpinning the social upheavals of the 1950s and 1960s. ' Sethna's case study of birth control and women's student activism at the University of Toronto in the 1960s is also useful for providing information on women's student activism in the period just before the formation of NUS. ${ }^{10}$ Lexier's exploration of student activism at the University of Saskatchewan, Regina Campus, reinforces Sethna's observations. Late 1960s women students on Canadian campuses were active in setting-up women's health services with the aim of distributing birth control information and giving abortion referrals. ${ }^{11}$ Pitsula also provides insight into the "women's liberation movement" at the Regina Campus in the late 1960s in the context of other liberation movements such as aboriginal rights and the crisis in Quebec. ${ }^{12}$

Histories of the so-called 'second wave' women's movement identify how student politics and organizations of the 1960s provided important spaces for the formation and organizational development of the women's movement. ${ }^{13}$ Yet, surprisingly, when this literature examines the post- 1972 period, it loses sight of the continuing socially productive power of women students in student movements and organizations. There is an oversight in the literature of the women's movement, whereby women's political activism in student movements is not acknowledged after 1972. There are some notable exceptions in studies of the post-1972 in Europe. ${ }^{14}$ More recently, women student organizing throughout the 1970s in the United States Student Association is acknowledged, but largely unexplored. ${ }^{15}$ Ross's work on student politics warrants attention here as she identifies a close tie between women and student movements in India throughout the entire century. ${ }^{16}$

\section{Late Sixties Background: the Canadian Union of Students (CUS)}

Clearly, NUS feminism was prefigured in CUS in the late 1960s and in the many 
more localized, campus-level expressions of feminism at this time. As early as 1965 , local members of the CUS were involved in pro-birth control campaigns on campus. ${ }^{17}$ Three years later CUS delegates passed a politically sophisticated motion simply called "women." 18 The motion was critical of capitalism, the institutions of marriage and family and "double exploitation." The motion concluded by resolving that "CUS and its member unions actively support the initiation of women's liberation groups, particularly within their own institutions and councils, and support the continuation of those groups already formed." Another motion called on CUS to support the establishment of women's centres.

By the time NUS formed in 1972, many Canadians and Federal Government politicians had embraced political and legal changes that potentially affected young women's lives. While abortion was decriminalized in 1969, the struggle to make it truly accessible was only beginning. Many women felt "cheated" by the new law on abortion that, in their minds, was far from ideal. ${ }^{19}$ Lexier asserts correctly that the women's movement (after 1969) "greatly changed the complexion of the student movement on campuses." 20

The women's liberation movement appeared in the Canadian Union of Students at a time when postwar economic growth was reaching its peak. However, in the early 1970 s, economic growth started to recede and the entire capitalist world-economy entered a period of relative economic stagnation. Throughout the 1970s, there was record high inflation and unemployment. So it is not surprising that unemployment was a top "priority" for youthful NUS activists, in contrast with the priorities of CUS whose resolutions suggest that unemployment was only a marginal concern. Economic changes, then, might have bifurcated the 'second wave' women's movement in Canada into different cohorts, roughly those associated with the general campus unrest of the mid-1960s to early 1970s and those associated with the period of economic restraint and cutbacks throughout the 1970s. I will now turn to a discussion of NUS politics more directly, starting with the organization's formation.

\section{NUS Women's Struggle for Rep resentation on the Central Committee}

The November 1972 "Founding Conference" of NUS at Carleton University worked toward writing a constitution that would determine how decisions would be made, especially given that some student councils represented many more students than others. The debate on 'representation' provided an important opening for women to raise the issue of their representation. After a great deal of discussion on representation, a motion was made calling for all committees to have an equal number of men and women. After an amendment was moved to exclude the Central Committee from this requirement, the motion carried with 24 in favour, 16 opposed and 8 abstentions. ${ }^{21}$

The discussion on representation, how decisions would be made, and by whom continued at the next General Meeting in May 1973 at Dalhousie University. The voting structure adopted was one vote per member institution. ${ }^{22}$ To fortify regional representation and balance-out Ontario's influence due to its higher population, each 
province would have a caucus and elect a representative to the Central Committee. The stakes were high because there was a distinct minority among the delegates who wanted NUS to continue in an activist and socially critical tradition rooted in the late $1960 \mathrm{~s}^{23}$ Inasmuch as the majority of delegates did not want to see NUS become like the Canadian Union of Students, NUS represented a kind of 'backlash politics' as moderate, conservative and anti-feminist male students asserted their influence within the national student organization. Such a 'backlash' sentiment was expressed well among the Atlantic delegates who rallied against Ontario student leaders. They did this not only because of the power Ontario could have had if the one vote per institution system had not been implemented, but also because Ontario delegates were associated with left-wing politics and the Ontario Federation of Students that had just led a province-wide tuition fee strike in the preceding winter 1973 term. $^{24}$ The debate was not simply about representation, but about the political form that NUS would take: mainstream/liberal, small 'c' conservative or socialist and oriented by social criticism and social justice concerns.

After much procedural wrangling and debate, the 'policy' on equal gender representation on committees was annulled: in fact, declared "ultra vires" or "beyond the authority. ${ }^{25}$ Faced with much opposition, advocates of equal gender representation such as Dawn Hassett from the University of British Columbia put forward a less demanding proposal. The idea of mandating equal gender representation on committees was dropped. ${ }^{26}$ Instead, it would be "recommended" that all committees have at least one-third female representation. ${ }^{27}$ The motion carried. But in specifying that this be only a recommendation, this was an empty victory. The UBC delegate stated, "I would like to see the requirements of one-third binding - it is my sense from this body that they don't want to see that." ${ }^{28}$ The minute-taker noted that NUS could not get one-third representation of women on committees because women made up less than one-third of the delegates. The UBC delegate addressed this criticism by replying that this was precisely why they needed such a clause in the motion - so that this gender imbalance might change. The implication was that student councils should immediately start recruiting and sending more female delegates to NUS meetings. ${ }^{29}$

One of the outspoken critics of women's representation suggested that enforcing equal gender representation might set a precedent, necessitating the representation of "any sort of minority group" on committees. ${ }^{30}$ While women were most certainly not a "minority group" given they made up about half of Canada's population, these men sensed correctly how NUS women were paving the way for other social justice concerns. Male NUS delegates were not of like mind; there are examples of men's support throughout NUS's existence. ${ }^{31}$ Craig Heron (representative from the newly formed Ontario Federation of Students) was one man who spoke in favour of equal gender representation: “for heaven's sakes men let's recognize that there is a problem here...." At one point in the debate, the UBC delegate retorted to her male opponents "We are establishing precedents and this is one of them." ${ }^{32}$ Through the actions of NUS women and supportive men, precedents were being set that would influence subsequent actions within the organization. In this case, women inserted themselves in the debate on fair representation (where only institutional size and geographic 
region had been discussed so far) by suggesting that representational fairness must also be promoted by having equal gender representation.

The outcome of the Founding Conference and the First General Meeting (GM) is key to understanding the trajectory of women's organizing in NUS. Without a mandate for equal or even one-third representation on the Central Committee (and other committees), the conditions for separate women's organizing within NUS was established. Male resistance to women's activism was an ongoing feature of gender relations within NUS and was a major determinant of the form of women's organizing in NUS. Reports of the women's committee often criticized the Central Committee for their inaction on women's directives carried at GMs. While there was obviously some male support for feminism in NUS, by and large, women gained representation in NUS not by getting elected to the Central Committee, but by carefully carving out their own spaces in the NUS organization. These separate spaces, the women's committees, caucuses, various local campus committees and eventually the pre-GM women's caucus conferences were material manifestations of women's activism (see next section).

By 1976, women had become much more involved in NUS decision-making, and at the May 1976 GM there were 3 women and 7 men on the Central Committee, the most women ever. However, over the next three GMs there was only one woman on the Central Committee (possibly two at the October 1977 Calgary GM). By the May 1979 GM, there were 4 women (and 7 men) and at the October 1979 GM there were 4 women (and 5 men), the closest yet to equal representation. It took approximately seven years for women to achieve (almost) what they initially sought at the founding conference: equal gender representation on the Central Committee. Despite the poor representation of women on the Central Committee between the October 1976 and the May 1978, there were many indications that women had become more organized overall. Throughout the mid-1970s, women increasingly focused on developing the women's committee/caucus and in taking on leadership roles in other areas of NUS organizing - in spite of the Central Committee. ${ }^{33}$ They kept up their pressure on the Central Committee, but focused their efforts elsewhere. This tactic appeared to be more productive than trying to get the Central Committee to act on women's behalf. It should be stressed that the growing presence of women in all aspects of NUS politics is not explained simply by their increasing numbers on campus but more by their awareness of and commitment to ending their under-representation. ${ }^{34}$

NUS GMs were held twice a year in May and October. Delegates to these meetings were selected by the local student councils; most often the student council president and other council executives were sent. This meant that women's participation at NUS General Meetings, including their election to the Central Committee was, in part, contingent on local student council willingness to pick women delegates. While each institution received only one vote, delegations were not limited in size but were usually two individuals and depending on the size of the member institution, sometimes as many as five individuals. At the GM, student council delegates would be joined by the NUS executive (the Central Committee), a handful of paid employees and a few invited guests. While there was a high turnover rate in the delegations 
between each GM, for both males and females, it was the Central Committee and paid-staff that provided a modicum of membership continuity, institutional memory and decision-making power.

As NUS organization documents indicate time and time again, Central Committee inaction thwarted the women's committee's initiatives. While women adjusted to Central Committee inaction by forming their own caucuses and committees, inaction was a persistent drag on women's organizing at least until 1978 when women were much better organized within NUS and involved with the Central Committee. Complaints to the Central Committee about the scheduling of women's meetings and workshops were constant. ${ }^{35}$ A review of the Central Committee reports shows consistently how well intentioned women-related motions arising at the previous GM got ignored. Women-related motions from GM to GM often repeated themselves, presumably due to Central Committee inaction. The initiative to produce a 'women's survival guide' for example, first suggested at the May 1975 GM dragged on for years and there was no evidence that the guide was ever completed.

\section{The Women's Caucus: the Creation of a Political Space}

For women to have a 'voice' in NUS, it was crucial that they first have a 'place' to speak from and coordinate their actions; that is, the women's committees and caucuses. NUS women's organizing was centred within the ever-changing women's caucuses, women's committees and in the various women's workshops. The relative importance of caucus, committee and workshop shifted from meeting to meeting and there seemed to be a great deal of nomenclature confusion throughout NUS's existence. ${ }^{36}$ Sometimes the committee would be referred to as "the caucus" and visa versa. While the committee was technically open to male NUS delegates, the caucus was definitely not. The women-only women's caucus was a continuous topic of controversy and was often challenged, especially in the beginning when it was first announced that men were not allowed to participate. Generally speaking, the workshops were places for men and women to discuss women's issues. As I explain below, "women's caucus" (where men were explicitly not invited) was used during those times when a minority of male delegates made it too difficult for mixed-gender discussion of matters of concern to women. By the end of the 1970s, the caucus and committee was more or less the same thing. Over time, the women's caucus became more organized and autonomous; male criticism lessened or became less noticeable; women were chairing more key committees; and women appeared more and more as NUS delegates. Such changes suggest not only an increasing status and authority of women in NUS but were also a concrete manifestation of the success of the organizational power of young women in the women's movement.

The 'to and fro' between committee and caucus and between pre-GM caucus meetings and the GM itself reflect the fundamental feminist organizing strategy that Adamson et al. identified as "mainstreaming and disengagement." 37 Temporary and periodic disengagement allowed women to discuss their concerns without male disruption and ridicule. Disengaged women's spaces, namely the women's caucus, 
enabled NUS women work on the mainstream 'from the margins'. That women's representation on the Central Committee in 1976 and 1977 decreased to early 1970s levels likely indicates a strategy of disengagement from the Central Committee. With the heightened development of the women's committee/ caucus, it was possible that women, disillusioned with the male-dominated Central Committee, stopped trying to get it to act on their behalf. They simply shifted their focus to the women's committee/caucus, which was becoming a stronger base of operations and a more productive and amiable place to expend one's time and energy. As Gillett points out in her history of women at McGill University, the pattern of men and women students working together in the same groups "shows anything but a consistent linear development from segregation to integration." 38 Clearly, what NUS women were doing was not something new to student women activists.

At the October 1973 GM, a motion was put forward to the plenary that a "women's caucus be on the agenda" of all NUS GMs. ${ }^{39}$ This was the first time "women's caucus" was ever mentioned in NUS. A motion to establish a "Standing Committee on the Status of Women" (basically the women's committee) was also carried. When the idea of a women's caucus was first accepted by the NUS plenary, the rules of the caucus were not openly discussed, that is, its women-only intent. I suspect its instigators purposely downplayed the "women-only" rule to avoid controversy.

At the next GM (May 1974), women met as a committee, but there is no evidence that a "women's caucus" was on the agenda, nor was there evidence that a women-only women's caucus met, formally at least. ${ }^{40}$ The records indicate that the motion to schedule a women's caucus was 'overlooked' by the Central Committee; committee and caucus were one of the same. At the next GM (October 1974), with some confusion among delegates, the name women's committee or more precisely the Standing Committee on Women was being used interchangeably with "women's caucus." Women at this meeting appeared content to be the "women's committee" rather than make a distinction between caucus and committee. ${ }^{41}$ It is likely that the "women's committee" operated without challenge until some male delegates publicly and formally challenged the women-only rule. At the next GM (May 1975), there was a highly debated motion that clearly defined "women's caucus" as "closed" and women's committee as open to men. Typifying the antagonistic male-dominating position in the debate, one male delegate quipped "If women wished to discuss personal problems they can do so informally." Marilyn Burnett stated that "it was necessary for women to get together at the start of a conference and decide what issues are important to them." There was no record of the motion actually being carried; nevertheless, a women's caucus was scheduled at the next meeting. ${ }^{42}$ At the October 1976 GM, the women's committee retreated completely into the women's caucus. The idea for a women's conference before each NUS GM was first proposed at this meeting.

As women became more organized and their concern with issues such as abortion and violence against women was more overtly expressed in NUS, criticism of the women-only women's caucus grew. Clearly, foes of abortion were directing their efforts against the women's caucus, the primary site of support for 'abortion on demand'. At the May 1977 GM, the motions arising from the women's workshop, all 
of which carried, include the reassertion of the women's caucus "as closed" and the women's committee as open "to all interested." 43 At the May 1978 GM, near the beginning of the plenary session, the issue of a 'closed' women's caucus appeared to receive its heaviest criticism so far. University of Toronto's Student Administrative Council (SAC) had sent a large contingent of five male delegates. SAC moved that "the women's caucus be open to all those attending the conference." ${ }^{44}$ Much procedural discussion ensued when Carleton University delegates raised a "point of order" claiming that it was not within the plenary's power to determine how caucuses were to be organized. The Chair allowed the plenary to vote on whether or not this was a valid point of order. The plenary agreed, and the Chair ruled that SAC's motion was "out of order" meaning that the women's caucus and any other caucus had the right to determine and control its own membership.

A particularly significant moment occurred at the next GM in October 1978: the Central Committee report, customarily made at the opening plenary of each GM, was for the first time, co-presented by a man and a woman (Bev Crossman). Thereafter, this formal and highly visible recognition of gender equality became a standard practice. This practice symbolized a new level of women's organizing in NUS.

The first motion arising from the women's caucus at the October 1978 GM urged student councils not to book the band, "The Battered Wives." This was a tactical motion related to the women's caucus new focus on violence against women. The band was slated to appear on Canadian campuses at a time when women students, particularly in NUS and those outside of universities, were becoming more conscious of, and active against, male violence toward women. A lengthy debate on the Battered Wives motion ensued. By and large, the debate was constructive, although one delegate said the motion was "somewhat ridiculous." After amendments were made to remove reference to the band's name, a revised motion carried. ${ }^{45}$ The band's name as well as "what it [allegedly] stood for" was considered a direct affront to those women who were taking-up the issue of violence in their activism.

It was likely that women started caucusing just before regular GMs as early as the May 1977 GM in order to brief each other and strategize. But certainly by 1978, preGM women's caucus meetings were standard practice and no doubt became a more integral part of coordinating women's activism in NUS and on campus. That the plenary voted at the May 1978 GM to support the Chair's competency and ruling on the autonomy of caucuses demonstrated again a new level of women's authority within NUS and how the cultural politics of NUS was shifting in favour of less patriarchal values. By 1979, the pre-GM caucus meetings were more formalized, and alternating half-day and full-day "conferences" were held. ${ }^{46}$ Women's organizing reached a peak in 1977 when the women's committee/caucus, for all intents and purposes, became a parallel, women- only version of the Central Committee. This was no organizational accident and was developed slowly and intentionally. At the May 1977 GM, a motion was carried to establish the "terms and reference" for the "national women's committee." The committee would have 10 representatives elected by "provincial/regional caucuses and a "national coordinator" to be elected from among these 10. This 
was basically the same structure as the Central Committee. ${ }^{47}$ In addition, the national women's committee (note it was now a "national" committee), would by-pass local student councils and forge direct links with campus level women's groups or committees. The successful resistance to challenges to the existence of women's caucus/ committee's, and after 1977, its greatly expanded organizational capacity — as a kind of parallel women-only Central Committee - were concrete material manifestations of women's authority and activism. Such organization changes also reflected broader shifts in how women were challenging and changing gendered social relations at a macro-societal level.

\section{Women Student Activism and NUS's Survival}

NUS women spent much time and energy on creating spaces for women in the NUS organization, not just in the women's committee/caucus but throughout the NUS organization and at local campus levels. NUS delegates, male and female, were constantly preoccupied with organizational development. In effect, NUS women were transforming the social relations and what Touraine called the "cultural orientations and values" of the NUS participants and in so doing were key social agents in the broader women's movement. ${ }^{48}$ From the attempts for equal representation of women on the Central Committee in the first formative meetings of NUS, women were involved in the building of the organization. Each new set of women delegates would enter into a slightly transformed historical field of action, the result of previous activism and organizational change. As I show below, NUS would probably not have survived after 1976 without the support that resulted from a 'critical mass' of women's organizational development in NUS.

Epitomizing women's involvement in the organizational development of NUS and in local campus culture, the women's caucus at the October 1976 GM called on NUS to "recognize the need for women to organize locally, provincially and nationally..." and for NUS to "do everything in its power to support these women and involve women students in the student movement generally." This meeting also proposed a more formal structure for the women's committee. ${ }^{49}$ Capturing the context of women students' organizing in 1976 and again epitomizing the situation of women's organizing in NUS overall, the minute taker recorded:

There were problems gaining women's involvement at the campus, provincial and national levels, including their participation on the staff of the organizations. Women have to be politicized, and the campuses that were strong in women's organization need a way to get their ideas and methods to the campuses where women are weak. NUS itself will be stronger if that half of the student population are active and involved in student issues. NUS's words in favour of women's participation are not worthwhile without activity, and activity requires advance planning...

Perhaps one of the most important aspects of women's participation in organizational 
development was expressed in their involvement in the 1975/76 NUS referenda campaign where every member of NUS was to vote for a higher fee structure and de facto remain in NUS. At the May 1974 GM, the Central Committee called for a membership fee hike to assure the continuation of a "socially active NUS." ${ }^{50}$ NUS wanted to raise the membership fee from $30 \$$ to $\$ 1.00$, which was not unreasonable considering the Canadian Union of Students fee in 1969 was \$1.50. Raising fees required membership referenda at each member institution. Fearing that NUS might become a more effective political force, a small minority conservative faction unsuccessfully opposed the fee-hike referenda.

NUS would have been faced with serious financial problems (and ability to campaign) if it had not been able to raise its membership fee. While most NUS delegates supported the higher membership fee, conservative, anti-student movement elements (within NUS since the beginning), mobilized against raising it. Dawn Hassett, main player within the women's committee and an early female member of the Central Committee, not surprisingly, supported moves to have a higher NUS membership fee structure. ${ }^{51}$ Concerns about the higher membership fee-that NUS might collapse in a series of referenda defeats - proved unfounded. NUS went on to win 27 and lose only 3 referenda in the 1975-76 academic year, which meant NUS's yearly income rose from $\$ 50,000$ to $\$ 150,000 .^{52}$

The women's committee not only supported the decision to have membership referenda, a risky and resource depleting endeavour, it appears to have been an important social agent in the referenda victories themselves. Just before the referenda blitz, at the Glendon College GM in May 1975, NUS made "women's issues" a formal priority (after student aid). This was an empowering moment for NUS women activists and a defining moment for NUS. It is unlikely NUS would have won campus membership referenda without the support of NUS women. It is possible that NUS could have collapsed, as the Canadian Union of Students did in 1968/69. But NUS benefited from having a critical mass of organized women students who were committed to building a national student organization..$^{53}$ Women had a long tradition of local campus organizing. In the early 1960s, at least, women students tended to be more involved in the local NFCUS Committee, in World University Service of Canada (WUSC) doing fundraising and event organizing. ${ }^{54}$ Women student organizers of the 1970s were thus traditionally well positioned locally to mobilize the YES NUS vote at the time the 1975/76 referenda campaign..$^{55}$ I suspect that the mid-1970s women's student mobilization was also a factor in the formation of provincial student organizations: the Atlantic Federation of Students (AFS), L'Association nationale des étudiants du Québec (ANEQ), the Federation of Alberta Students (FAS) and the British Columbia Federation of Students (BCFS).

Three other factors contributed to women's support for NUS in the membership referenda: a) the population of women students was the highest it had even been in the history of Canadian postsecondary education; b) International Women's Year was in 1975 and women were particularly active; and c) women could point to NUS as an important organization representing their interests.

With the new fee in place, by 1977 , NUS finances were in much better shape. 
The student population had also grown and this meant more income for NUS (and student councils). NUS could spend more on informational materials, hire more full-time staff and support financially the development of the women's committee. NUS activism against education funding cuts intensified and the organization was in better financial shape to confront provincial government induced fee hikes that started in the late 1970s. ${ }^{56}$ NUS's new newspaper, the Student Advocate would be used to "highlight women and cutbacks." ${ }^{57}$ Also contributing to NUS's financial standing and legitimacy was the fact that it reunited with the service wing of the national student organization that had been on its own since the collapse of CUS in $1969 . .^{58}$

Thus far, I have discussed several key aspects of NUS women's activism: their struggle for representation on the NUS Central Committee, the formation of the women's caucus, and their central role in helping NUS survive as a viable national student organization. I will now turn to two other important areas of NUS women's influence on the NUS organization: the campaign to have NUS officially endorse a women's right to abortion, and the formation of Declaration of the Rights of the Woman Student.

\section{NUS and Abortion}

The first initiative related to abortion appeared at the October 1973 GM. ${ }^{59}$ A motion carried calling for the repeal of the abortion laws and for charges to be dropped against Dr. Morgentaler, the famous Montreal doctor who openly disregarded the abortion laws. Unfortunately the tape-recording of this meeting was stolen (the basis of the verbatim minutes) so there is a poor record of the debate. Yet it appeared that this motion did not elicit much opposition if the record of debate at the May 1975 GM was any indication. The more detailed minutes of this GM indicated few criticisms after a motion was put forth calling for "the repeal of section 251 of the Criminal Code", "amnesty for Dr. Morgentaler," and for NUS and NUS members to write letters to the Minister of Justice and the Prime Minister. Why these motions did not appear to cause much debate, as they did at later meetings, is unclear. Was it that the motions were strategically worded - they did not seem to propose a clear policy on abortion - to ensure easy acceptance in the plenary? Was it that the pro-life movement was not yet organized on campus? The abortion motions were directives to the male-dominated Central Committee, and since Dawn Hassett, an activist from the May 1973 meeting, was on the Central Committee, I assume action was taken.

There is no more mention of abortion until the May 1978 GM. One can only speculate as to the reasons for this. It would be hard to believe that abortion was not discussed internally at women's caucus meetings but is conspicuous by its absence in the women's reports. Whatever the case, abortion rights suddenly appear as a major controversy, starting at the May 1978 GM. At this GM, the women's caucus put forward just one motion. 
BE IT RESOLVED THAT NUS strongly opposes the current campaign on the part of the anti-choice movement to stack federal nomination meetings, and THAT NUS strongly urge all member and non-member campuses to join active vocal campaigns to combat this trend.

As before, the abortion motion was carefully worded. Technically, it was not a motion to support or not support abortion, but a motion to resist the actions of "anti-choice" organizers. While 'whereas' statements are usually not considered important or legally binding — it is the 'Be it resolved' statements that counted — in this case the premise statement was loaded with significance. It read "WHEREAS NUS recognizes that abortion is a matter of personal choice for the woman involved." While the reference to "personal choice" was in the "whereas' statement where it considerably reduced its legal meaning, nevertheless it was the closest so far NUS had come to articulating a pro-choice orientation. The abortion motion carried (recorded in a "roll-call vote") with 12 in favour, 2 against, 13 abstentions and 2 absent. The University of Toronto's Students Administrative Council (with a delegation of 5 men), and who had earlier in the meeting unsuccessfully challenged the right of women delegates to caucus without men, voted No. The reasons SAC gave were "NUS should not get involved in this [abortion rights]. It was offensive to many constituents and colleges, particularly their own, and would cause substantial problems." A York University delegate said "the motion [should] be left until students' councils or student bodies be consulted." Such arguments against the motion evidently influenced many delegates to vote No and Abstain. Yet many others were prepared to make a forceful stand on a concern central to the women's movement. ${ }^{60}$

At the following GM (October 1978) abortion was not mentioned in the motions arising from the women's committee and in the proceedings of most of the meeting. However, a commotion erupted on the plenary floor when the women's committee report was finally presented. In the absence of a statement on abortion, some women broke ranks with the women's committee and insisted that a motion to endorse the international campaign on abortion rights be included. The Chairperson deferred the debate to the end of the last plenary, the customary place for controversies. When the controversial motion was finally brought forward "THAT NUS/UNE recognize and endorse the international campaign on abortion rights," it failed to carry and the GM ended on a sour note for the proponents of choice on abortion. It appears that there was lack of consensus in the women's committee on how to proceed with the abortion issue. It is possible that the majority were opting for "disengagement" on the issue of abortion, as was likely the case in 1976 and 1977. But for some, a significant minority in the women's committee, it was clear that this was no longer an option. Motions to support NUS involvement in International Women's Day (IWD) carried, but only because reference to abortion was excluded.

Although NUS did not pass a clear policy on abortion until 1979, the activism leading to it reflected the intense commitment and organizing abilities of university women in the 1970s. 


\section{The Declaration of the Rights of the Woman Student}

A woman's right to abortion was by far the most contentious issue in the debate leading up to the Declaration of the Rights of the Woman Student at the October 1979 GM. ${ }^{61}$ None of the other issues in the Declaration received criticism, which attests to the success of women's agency in NUS and the success overall, of the women's movement. Speaking directly to the issue of abortion during the debate on the Declaration, a minority of students said, as they had said before, "they did not have a mandate to vote." This was no longer a valid excuse, as they would have had plenty of time to seek such a mandate on their home campuses. Clearly local campus conditions as well as personal convictions were factors in how delegates voted. Further research at local campus level would be revealing here. That some delegates were being directed by their student councils to remain neutral is conceivable; anti-abortion activism on campuses was a likely factor. That local campus "mandates" on abortion had not yet been sought reflected the ongoing problem of women's marginalization on student councils and no doubt the increased organization abilities of anti-abortion movements in the late 1970s. During the debate that led to the acceptance of the Declaration, there was a motion to split off the section on abortion from the Declaration and vote on it separately. But the mood was discernibly different to that of the October 1978 GM. The women's committee and movers of the motion to accept the Declaration were more united and evidently more confident. The motion to separate out the references to abortion was defeated.

The Declaration was undoubtedly a major achievement for the women's movement. It brought together in a single comprehensive statement the many problems that student women had named and issues that they had struggled for over the course of NUS's existence. The Declaration included statements in support of women's right to access all fields in post-secondary education, to organize within the student movement, to "equal opportunity to employment with equal pay for work of equal value," to better childcare and pay for childcare workers, to have a non-sexist student aid system, to receive women's studies courses, to be free from "verbal and physical harassment," to have access "to birth control and the right of choice in the method," to "control their bodies and their sexuality" and to "freedom of choice in the matter of abortion." The Declaration also contained the first-ever official NUS reference to the gay/lesbian rights movement and "sexual orientation," and included the statement that "freedom of choice in sexual orientation is a fundamental human right." The issue of "sexual orientation" seemed to have come out of nowhere; its inclusion is striking, as there was nothing about sexual orientation in the organization records of previous GMs.

The Declaration epitomized the new position of women in NUS and on campus overall. It represented the culmination of years of women students' efforts to articulate and solve the problems of women students. The motion to accept the Declaration carried, 20 in favour, one against with 8 abstentions. The Declaration was dedicated to the memory of Joyce Andres who had "helped bring the NUS women's caucus to where it is today." ${ }^{62}$ By the time of the Declaration, there had been a marked 
development in women's organizing within NUS, even compared to just one or two years earlier. While NUS had changed its political orientation significantly over 7 years, its work was not done: the struggle against sexism and patriarchy continued.

\section{Conclusion}

That such a Declaration could be articulated and endorsed was a major achievement. The social movement that led to the Declaration was also significant in that it prefigured, that is, it set the stage for future student movements against racism, colonialism, ableism and homophobia. Although the Declaration needs to be understood as an important moment in NUS and student organization history, it was clear that the struggle against racism and other 'isms' had barely started. The Declaration avoided discussion of other serious social inclusions - issues of race, physical ability, and aboriginal people were not included. This is surprising given that such issues had been discussed at earlier GMs. The issue of racism first appeared in 1978 when a motion carried urging measures to counter "racist groups." ${ }^{63}$ Precedent setting motions expressing concern for "handicapped students" came in 1979. ${ }^{64}$ Motions supporting aboriginal rights appeared in CUS in the late 1960s but it took NUS until 1976 to make similar motions. ${ }^{65}$ Interests in aboriginal rights as well as issues of racism do not appear to be sustained throughout the rest of the 1970 s. $^{66}$ The issue of 'class' was obliquely represented in terms of support for access to education, but it was far from being an expression of socialist feminism as articulated 10 years earlier in the Canadian Union of Students. Further study of the post-1979 period would likely reveal that the success of 1970s women students through organization and determination appears to provide an organizational blueprint and cultural legacy on how to organize for social justice.

There is little doubt that women student leaders in NUS in the 1970s, through their activism, profoundly affected the NUS organization. The women activists of NUS succeeded in finding a place for themselves by transforming the organization from a patriarchal one to one which better respected the rights of men and women collectively. While it is clear that women students made significant gains in the national student organization throughout the 1970s, it is also clear that women's rights were never completely secure in subsequent periods: the gains of the 1970s could not be (and were not) taken for granted.

Just how much bearing did young educated women have (and continue to have) in broader socio-cultural transformations and in the women's movement? While the answer to this question is beyond the scope of this article, one thing is certain: the feminists of NUS should not be viewed as a derivative of a women's movement happening elsewhere or as some sort of inconsequential backwater of the women's movement. NUS women, among other activists in many other locations, were the women's movement. In fact, this research suggests that women (and supportive men) not only transformed NUS but were also social agents of a much wider process of social transformation. 


\section{Notes}

1 See Diana Pedersen. "The Call to Service': The YWCA and the Canadian College Woman, 1886-1920," in Youth, University and Canadian Society: Essays in the Social History of Higher Education, eds. Axelrod and Reid (Montreal: McGill-Queen's Press, 1989); Paula LaPierre, The First Generation: The Experience of Women University Students in Central Canada (Ph.D. diss., University of Toronto, 1993); Alyson Elizabeth King, The Experience of the Second Generation of Women Students at Ontario Universities, 1900 1930 (Ph.D. diss., University of Toronto, 1999); Sara Z Burke, "New Women and Old Romans: Co-education at the University of Toronto, 1884-95," Canadian Historical Review 80, 2, (1999): 219-41; Charles Levi, Comings and Goings, University Students in Canadian Society, 1854-1973 (Montreal and Kingston: McGill-Queen's Press, 2003); Catherine Gidney, "Under the President's Gaze: Sexuality and morality at a Canadian university during the Second World War," The Canadian Historical Review, Vol. 82, 1 (March, 2001) and "Dating and Gating: The Moral Regulation of Men and Women at Victoria and University Colleges, University of Toronto, 1920-60," Journal of Canadian Studies, 41, 2 (Spring 2007).

2 See Margaret Gillett, We Walked Very Warily: A History of Women at McGill (Montreal: Eden Press, 1981); Anne Rochon Ford, A Path Not Strewn with Roses: One Hundred Years of Women at the University of Toronto (Toronto: University of Toronto Press, 1985); A. B. McKillop, "Marching as to War: Elements of Ontario Undergraduate Culture 1880-1914" in Youth, University and Canadian Society: Essays in the Social History of Higher Education, eds. Axelrod and Reid (Montreal: McGill-Queen's Press, 1989); Lee Stewart, "It's Up To You": Women at UBC in the Early Years (Vancouver: UBC Press, 1990); Veronica Strong-Boag, Veronica. The New Day Recalled: Lives of Girls and Women in English Canada, 1919-1939 (Toronto: Copp Clark Pitman, 1993); Martin Friedland, The University of Toronto: A History (Toronto: University of Toronto Press, 2002).

3 Paul Axelrod, Making a Middle Class, Student Life in English Canada during the Thirties (Montreal: McGill-Queen's University Press, 1990),117.

4 Charles Levi, Decided Action Has Been Taken' Student Government, Student Activism, and University Administration at the University of Toronto and McGill University 1930-1950, (Master's Research Project, Revised Version, Department of History, York University, 1994).

5 Myna Kostash's Long Way From Home - The story of the Sixties Generation in Canada (Toronto: Lorimer, 1980).

6 Judy Bernstein, Peggy Morton, Linda Seese and Myrna Wood, "Sisters, Brothers, Lovers... Listen ...." In Women Unite! An Anthology of the Canadian Women's Movement (Toronto: Canadian Women's Education Press, 1972).

7 See Dimitrios Roussopoulos, "Towards a Revolutionary Youth Movement and an ExtraParliamentary Opposition in Canada," in The New Left in Canada, Roussopoulos ed. (Montreal: Black Rose Books-Our Generation Press, 1970), 141-2

8 Cyril Levitt, Children of Privilege, Student Revolt in the Sixties. A Study of Students Movements in Canada, the United States and West Germany (Toronto: University of Toronto Press, 1984).

9 Doug Owram, Born at the Right Time: A History of the Baby Boom Generation (Toronto: University of Toronto Press, 1996).

10 Christabelle Sethna, "The University of Toronto Health Service, Oral Contraception, and Student Demand for Birth Control, 1960-1970," Historical Studies in Education/ Revue d'histoire de l'éducation, 17, 2 (2005): 265-92.

11 Roberta Lexier, Student Activism at the University of Saskatchewan, Regina Campus, 1961-1974 (M.A. thesis, University of Regina, 2003).

12 James M. Pitsula, New World Dawning, the Sixties at Regina Campus (Regina: Canadian Plains Research Center, 2008), 153-168. 
13 Naomi Wall, "The Last Ten years: A Personal-Political View," in Still Ain't Satisfied! Canadian Feminism Today, eds. M. Fitzgerald et al. (Toronto: Women's Press, 1982): 16-17; Nancy Adamson, Linda Briskin and Margaret McPhail, Feminist Organizing for Change, the Contemporary Women's Movement in Canada (Toronto: Oxford University Press, 1988), 39-44; Naomi Black, "The Canadian Women's Movement: The Second Wave," in Changing Patterns: Women in Canada, eds. S. Burt. L. Code and L. Dorney (Toronto: McClelland and Stewart, 1988),83; Jill Vickers, "The Intellectual Origins of the Women's Movements in Canada," in Challenging Times. The Women's Movement in Canada and the United States, eds. C. Backhouse and D. H. Flaherty (Montreal: McGill-Queen's University Press, 1992), 46-48; Majorie G. Cohen, "The Canadian Women's Movement," in Canadian Women's Issues. Strong Voices. Vol. 1, eds. R. R. Pierson et al. (Toronto: James Lorimer and Co., 1993), 4; Lorraine Code, "Feminist Theory," in Changing Patterns: Women in Canada, eds. Burt et al. (Toronto: McClelland and Stewart, 1988: Judy Rebick, Ten Thousand Roses, the Making of a Feminist Revolution (Toronto: Penguin, 2005); for the US context, see Sara Evans, Personal Politics (New York: Alfred A. Knopf, 1979); Gail Paradise Kelly, "Women’s Liberation and the New Left," Radical America, IV, 2 (1970): 19-25; Wini Breines, Community and Organization in the New Left: 1962-1968, the Great Refusal (New York: Praeger, 1982); Stephanie Gilmore, Feminist Coalitions, Historical Perspectives on Second-Wave Feminism in the United States (Chicago: University of Illinois Press, 2008).

14 See Frigga Haug, "The Women's Movement in West Germany," New Left Review, 155 (1986): 50-74. A 'youth wing' in the British women's movement of the 1970s is at least acknowledged by Angela Weir and Elizabeth Wilson, "The British Women's Movement," New Left Review, 148 (1984): 74-103.

15 See Angus J. Johnston, The United States National Student Association: Democracy, Activism, and the Idea of the Student, 1947-1978 (Ph.D diss., New York: City University of New York, 2009).

16 Aileen D. Ross, Student Unrest in India; A Comparative Approach (Montreal, London, McGill-Queen's University Press, 1969).

17 Canadian Union of Students, Resolutions (1965), 18. Twenty Ninth Congress, Bishop's University, Quebec, Aug. 29-Sept. 4.

18 Canadian Union of Students, Resolutions (1968), 6, Thirty Second Congress, University of New Brunswick.

19 The new law stipulated that before an abortion would be granted, the pregnant woman had to go before a panel of 4 doctors (usually male) and plead excessive psychological trauma (see Kostash, Long Way From Home, 175).

20 Roberta Lexier, Student Activism at the University of Saskatchewan, Regina campus, 1961-1974, 91-92.

21 NUS Minutes, Founding Conference, 1972, 10, Carleton University, Ottawa, Ontario, November 3-5.

22 NUS Minutes, First Annual General Meeting, Evening Session, Dalhousie University, Halifax, Nova Scotia, May 4-6 (1973).

23 See Minutes, Founding Conference; see also Bruce Cameron, "New National Student Union” (CUP), Lambda, Laurentian University, Sept. 12 (1972), 6; Lynda Woodcock, "New Union 'Exorcising' Ghost of CUS," University Affairs, Oct.; Paul Axelrod, Scholars and Dollars: Politics, Economics, and the Universities of Ontario 1945-1980 (Toronto: University of Toronto Press, 1982), 201.

24 See Nigel Moses, "Forgotten Lessons: Student Movements Against Tuition Fee Hikes in Ontario in the 1960s and 1970s," trans/forms, insurgent voices in education 7 and 8 (June 2004): 136-176.

25 Minutes, May 4-6 (1973): 8-10, "First Day."

26 Ibid., "Meeting-Saturday," 4-9.

27 Ibid., 18. 
28 Ibid., 7.

29 At the two GMs in 1973, only about 5 women were in attendance each time (roughly 10 per cent of the delegates); at the 1976 GMs, there were roughly 29-34 women each time (roughly 25 per cent) and by the October 1979 GM, about 60 women (roughly 45 per cent).

30 Minutes, May 4-6 (1973), 8.

31 The minutes record a great deal of male animosity toward women's organizing at General Meetings. However, there must have been majority male support or else women's motions would never have carried. Men's support for the women's agenda was best expressed in the pro-feminist "men's caucus" held at the May 1976 GM. Apparently it was a one-time only event.

32 Minutes, May 4-6 (1973), 8.

33 See for example the Workshop on NUS - a Working Union, chaired by Sue Goldberg, NUS Minutes, Second Annual General Meeting and Third Conference, Simon Fraser University, Burnaby, B.C., May 1-5 (1974), 11-15; Women were involved in campaigns for student aid and employment (see for example NUS Minutes, Third Annual General Meeting, Glendon College, Toronto, Ontario, May (1975), 6, Item 4; and Debra Lewis, "Summer Employment for Students - an Overview," unpublished paper, submitted to Third Annual General Meeting, May 1-5, Glendon College (1975), 4-5.

34 Women's university enrollment (full and part-time, undergraduate and graduate) between 1970/71 and 1980/81 went from 37 to 50 percent of total student enrollment (part-time alone went from 42 to 60 percent), Women in Canada, a Statistical Report, Cat. 89-50E (Ottawa: Statistics Canada, 1985). Throughout the 1950s and 1960s, women's participation in national student organization meetings stayed consistent: around the 15-17 percent mark - despite increasing female enrolment throughout this period (see NFCUS Resolutions between 1948 and 1962, and CUS Resolutions, 1965, 1968). Women's participation at the first two NUS meeting in 1973 in comparison was 10 percent, in fact a significant drop in participation rate from the last two decades, see Minutes, First Annual GM (1973) and "Minutes of the Second Annual General Meeting of the NUS" [sic], University of Alberta, Alberta, October 19-21 (1973).

35 See for example, NUS Minutes, Tenth Semi-Annual General Meeting, Mount Royal College, Calgary, Alberta, October 21-23 (1977), 17.

36 See for example Report of the Standing Committee on Women, "Minutes of the Conference of the NUS," University of Saskatchewan, Saskatoon, Saskatchewan, October 11-14 (1974),12-13.

37 Adamson et al. Feminist Organizing for Change.

38 Gillett, We Walked Very Warily, 233.

39 Minutes, October 19-21 (1973): 20).

40 See Minutes, May 1-5 (1974), Agenda and Diagram of Agenda, in cerlox bound conference documents.

41 See Minutes, May 1-5 (1974), The Report of the Standing Committee on Women.

42 See Agenda, in cerlox bound conference documents, NUS Minutes, "Sixth Conference" [General Meeting], University of New Brunswick, Fredericton, New Brunswick, October 16-19 (1975).

43 NUS Minutes, Fifth Annual Meeting, The Charlottetown Hotel and Holland College, Charlottetown, Prince Edward Island, May 10-14 (1977), 46.

44 NUS Minutes, Sixth Annual Meeting, NUS, Memorial University, St. John's, Newfoundland, May 10-14 (1978), 15.

45 NUS Minutes, Twelfth Semi-Annual Conference, University of Western Ontario, London, Ontario, October 12-15 (1978), 20-22.

46 See NUS Minutes, Eighth Semi-Annual Conference, Carleton, Ottawa, Ontario, October 1-3 (1976), 25; Minutes, October 12-15 (1978), 22; see also "Standing 
Resolution Number Five," NUS Minutes, Seventh Annual Meeting, University of British Columbia, Vancouver, B.C, May 9-13 (1979).

47 See motions arising from the Affirmative Action for Women workshop report, Minutes, May 10-14 (1977), 44-46.

48 See for example, Alain Touraine, Return of the Actor: Social Theory in Postindustrial Society, M. Godzich. Trans. (Minneapolis: University of Minnesota Press, 1988).

49 Minutes, October 1-3 (1976), 25.

50 Minutes, May 1-5 (1974), Report from the NUS Standing Committee on the Structure and Financing of Student Unions; and Addendum of Central Committee.

51 Minutes, October 11-14 (1974).

52 Anonymous, "Students Build Organization to Deal with Student Related Issues at the Federal Level," Student Advocate, (January, 1977), 8; Anonymous, "An Orientation to the NUS. "It's (sic) development and current operation," Materials for Delegates, Minutes, May 10-14 (1978), 15.

53 While further research is warranted here, the lack of enthusiasm for a sexist CUS by feminist women student organizers in the late 1960s, strengthened by a strategy of disengagement, were most likely among the factors in the string of referenda defeats that led to the demise of CUS between 1968 and 1969.

54 Personal Interview, wife of former NFCUS president, 1992.

55 See Minutes, October 19-21 (1973), 19.

56 Moses, "Forgotten Lessons" (2004).

57 The Student Advocate from September 1976 to February 1981 does not appear to be a major component of women's organizing in NUS. However, key articles on women's issues can be found, starting in the November 1977 issue. The Declaration was printed in the November/December 1979 issue.

58 See Minutes, May 10-14 (1978), "Association of Student Councils Canada, abbreviated historical outline, "in Material for Delegates.

59 Minutes, October 19-21 (1973), 23.

60 See Minutes, May 10-14 (1978), 89-91.

61 NUS Minutes, Fourteenth Semi-Annual NUS Conference, University of Regina, Regina, Saskatchewan, October 11-14 (1979), 90.

62 Ibid., Eulogy, 26-30.

63 Minutes, October 12-15 (1978), 32.

64 Minutes, May 9-13 (1979), 25, 27.

65 Minutes, Forth Annual Meeting, University of Winnipeg, Winnipeg, Man., May 12-16 (1976), 50-53.

66 For one exception, see motion in Minutes, May 9-13 (1979), 27. 